\title{
Long-term Central Waikato summer-autumn rainfall and pasture growth trends. Are conditions for pasture growth changing over time?
}

\author{
Chris B GLASSEY ${ }^{1, *}$, R. Grant WILLS ${ }^{4}$, Mike B DODD ${ }^{2}$, Kieran S McCAHON ${ }^{1}$ and David F CHAPMAN ${ }^{3}$ \\ ${ }^{1}$ DairyNZ, Private Bag 3221, Hamilton 3240, New Zealand \\ ${ }^{2}$ AgResearch, 11 Dairy Farm Road, Palmerston North 4442, New Zealand \\ ${ }^{3}$ DairyNZ, 24 Millpond Lane, Lincoln 7608, New Zealand \\ ${ }^{4} 93$ Paratu Road, RD1, Matamata 3475, New Zealand \\ *Corresponding author: chris.glassey@dairynz.co.nz
}

\begin{abstract}
Farmers in the upper North Island are concerned about the poor productivity of their perennial ryegrass pastures beyond 3 years and suggest this is linked to a trend towards drier conditions for pasture growth during summer and autumn. To explore how conditions for pasture growth and survival have changed, trends in rainfall (measured and interpolated; c. 1954 to 2020), frequency of soil moisture deficit stress on pasture growth (1972-2020), and pasture growth rates (simulated 1977-2020, and measured c. 1979-2020) were compiled for summer-autumn months (November to April) for two Waikato locations: DairyNZ Ruakura/Scott Farm near Hamilton; and a commercial farm at Paratu Road between Morrinsville and Matamata. Significant negative linear trends were observed for interpolated rainfall (Paratu Road only), total stress days (both sites) and simulated pasture growth (both sites). No significant trend in measured pasture growth was observed for either site, suggesting adaptive management has cushioned the physical effects of harsher climatic conditions. The suite of adaptive management practices adopted on the Paratu Road farm is described. Analysis of decadal patterns indicated greater variability in rainfall in the decade 2011-2020 (coefficient of variation ranging from 32\% to $36 \%$ depending on site and data source, versus 22\% in earlier decades) and a significantly higher number of stress days in the decade 2011-2020 compared with the 1970s and 1980s at Paratu Road. Further adaptation strategies will be needed to mitigate these most-recent trends, should they continue as predicted by climate change forecasts.
\end{abstract}

Keywords: perennial ryegrass, persistence, summer moisture deficit trends, Rezare Pasture Growth Forecaster, Virtual Climate Network

\section{Introduction}

Future climate change projections for New Zealand point to temperature increases, particularly in summerautumn; more frequent hot days; precipitation decreases in northern and eastern regions; and increased drought severity (Mullan et al. 2018). In central Waikato, farmers are already concerned that summers and autumns in recent years have been more variable, and generally drier and warmer than normal, resulting in more challenging conditions for pasture growth. Farmers are also noticing increasing costs and effort for maintaining their pasture base and this is reflected in costs recorded by dairy industry economic surveys (Dodd et al. 2018).

Evidence to support these farmer observations is sparse. Glassey (2011) reported a decline in mean December to April rainfall at Ruakura of around 40 mm per decade since 1979 , an increase in variability of rainfall with coefficient of variation $(\mathrm{CV})$ increasing from $19 \%$ in the 1980 s and early 1990 s to $29 \%$ in the early $2000 \mathrm{~s}$, and a negative relationship between rainfall and cumulative pasture growth $(-85 \mathrm{~kg}$ dry matter (DM)/ha per $10 \mathrm{~mm}$-reduction in total rainfall). These trends, and their potential effects on other pasture performance factors such as pest outbreaks (Ferguson et al. 2019), result in increased risk to pasture persistence which is reflected in farmer observations (Tozer et al. 2011) and confirmed in trial data (Lee et al. 2017).

This between-year variability for central Waikato summers, which are often dry, means that recent dry years need to be placed in an historical context to help identify the right adaptation strategies for the future dairy forage base in the region. Since 2010, measurement of pasture growth at the site reported by Glassey (2011) has continued. A long-term pasture growth dataset was also available from a local commercial dairy farm. In addition, models are available for evaluating long-term trends for summerautumn pasture growth for Waikato locations based on profile available water (PAW, as defined in Overseer ${ }^{\mathrm{TM}}$ ) and actual climate data, e.g., the Rezare Pasture Growth Forecaster (Ogle 2015). Simulation of pasture growth enables an analysis independent of other farm system influences (e.g., fertiliser, supplement use and grazing management) which may help elicit the extent to which those farm systems management factors may already be off-setting climate-driven trends in pasture production. This is useful for helping gauge what capacity exists for adaptation (albeit likely to add to costs of production) 
versus the need to develop further adaptation measures.

The objective of this study was to investigate longterm rainfall trends and the combined impact of rainfall plus soil moisture stress on plants over the summerautumn months and how these have affected conditions for summer-autumn growth of perennial ryegrass-based pastures in the central Waikato region, particularly over the past 4 decades.

Both measured and modelled pasture growth were used for this purpose, noting that data for measured pasture growth over periods greater than 3 to 5 years are sparse. We also note that 4 decades is still a relatively short time from which to draw firm conclusions given the evidence for decadal-scale climate patterns (Interdecadal Pacific Oscillation, Folland et al. 2002). We therefore put forward observations rather than firm conclusions and, in so doing, highlight the critical data/ knowledge gaps that should be addressed to provide clearer messages for farmers about their exposure to risk and associated adaptation options.

\section{Materials and Methods}

Analysis of long-term climate and pasture growth trends focussed on two central Waikato locations, encompassing two research farms east of Hamilton (Ruakura No. 2 dairy, and DairyNZ's Scott Farm at Newstead) and a commercial dairy farm $21 \mathrm{~km}$ south of Morrinsville (Paratu Road). This analysis included both actual and modelled pasture growth data from various sources as outlined below.

\section{Weather and climate data}

Daily rainfall records from the Ruakura climate station (National Institute of Water and Atmospheric Research (NIWA) 26177 EWS, latitude 37.7757 south, longitude 175.3051 east) were aggregated into monthly rainfall totals for November to April (incl.) from 1954 to 2020. The 6 months from November to April were chosen as the months where it was most likely that the interaction between rainfall and potential evapotranspiration creates soil moisture deficits that affect pasture growth. This was called the summer-autumn period and aligns with the November-January and February-April months as defined for the upper North Island for the DairyNZ Forage Value Index (DairyNZ 2021). The variability $(\mathrm{CV} \%)$ of rainfall for November to April for the Ruakura climate station was calculated for each decade over this period.

Interpolated climate data were available from the Virtual Climate Network (VCN, Tait et al. 2006), which uses daily NIWA climate station records (NIWA 2020) to estimate values for a network of sites across New Zealand on a $5 \mathrm{~km}$ grid. VCN data from 1960-2020 for the grid node nearest to the Paratu Road farm (latitude 37.4511 south, longitude 175.3842 east), and another grid node nearest Scott Farm (latitude 37.4606 south, longitude 175.2200 east), were examined for longterm rainfall and soil moisture deficit trends over six months from November to April, and rainfall for each individual month within that period.

\section{Net herbage accumulation (HA) Simulated net HA}

Pasture growth modelling was used to translate long-term weather patterns into potential pasture production, independent of the effects of changes in farm management (e.g., stocking rate, soil fertility). The Rezare Pasture Growth Forecaster (Ogle 2015) was used to simulate daily pasture growth potential for the two sites from November 1977 to May 2020 (based on the availability of daily weather data from the VCN). The model utilises information on farm type, geographical location, plant available water, daily weather, fertiliser and irrigation inputs to generate daily changes in pasture biomass (Romera et al. 2009, 2013). Pasture growth potential in the model is influenced strongly by temperature and moisture growth-limiting factors that are combined into a single stress index. This index typically accumulates during summer when pastures are moisture-limited and temperatures are high, then declines during autumn as moisture and temperature stresses are alleviated. Predicted daily net HA (kg DM/ha/day, Hodgson 1979) and the daily value of the stress index, were compiled for each of the 43 growing seasons to indicate long-term trends in climatically induced stress and annual pasture production, as per Dodd et al. (2018).

For the two locations, the site-specific input data for the model included the daily weather file from the nearest VCN node and the soil profile available water (PAW) from S-Map (https://smap.landcareresearch. co.nz/) for the predominant soil type on each farm. For Scott Farm PAW was set at $198 \mathrm{~mm}$ (Matangi silt loam) and for Paratu Road the PAW was set at $133 \mathrm{~mm}$ (Te Rahu silt loam).

Using the VCN data we calculated a daily soil moisture balance for summer-autumn based on incoming daily rainfall $(\mathrm{mm})$, minus daily potential evapotranspiration (PET, mm), and a fixed available water capacity (PAW, the amount of water in the soil 'reservoir' that plants can use). From this we determined the number of "stress days" for each year where plant roots take up water with increasing difficulty and plant growth is restricted.

\section{Measured net HA}

Measured monthly pasture growth rates were collated for summer-autumn (November to April) from two research sites and one commercial dairy farm.

Records from Ruakura No. 2 Dairy (1979-2004) and 
then Scott Farm (2004 to 2020) were compiled, the latter adding 10 additional years to a previous analysis (Glassey 2011). These two farms are less than $5 \mathrm{~km}$ apart and have similar perennial ryegrass/white cloverdominant pastures. They are referred to hereafter as 'Scott Farm'. The following data were analysed for between-year variability in summer-autumn net HA.

- Monthly net HA for the 'control' farmlet at Ruakura No. 2 Dairy from June 1979 until May 1993. Data from 11 of 13 years were available. No nitrogen $(\mathrm{N})$ fertiliser was applied to pastures during this period.

- Monthly net HA for the 'control' farmlet at Ruakura No. 2 Dairy from June 1993 until May 2004. During this period annual $\mathrm{N}$ fertiliser application to pastures averaged $186 \mathrm{~kg} \mathrm{~N} / \mathrm{ha}$.

- Monthly net HA for the 'control'/'benchmark' farmlet at Scott Farm from June 2004 to May 2020. During this period, annual $\mathrm{N}$ fertiliser applications averaged $182 \mathrm{~kg} \mathrm{~N} / \mathrm{ha}$, and pasture renewal occurred with updated cultivars on approximately $5 \%$ of the farm area each year.

The 'control' farmlets at No. 2 Dairy and Scott Farm were stocked at 3.0 cows/ha. Management decision rules were applied as described by Macdonald \& Penno (1998).

Monthly net HA data for the farmlets were derived from pasture cover assessments conducted weekly by visual assessment for each paddock, calibrated with ground-level herbage cuts. On each occasion, a minimum of 10 calibration quadrats (each $0.2 \mathrm{~m}^{2}$ ) covering the range of herbage mass present were set out and assessed visually. After assessment the quadrats were cut to ground level, washed and dried in a forced draught oven at $95-100^{\circ} \mathrm{C}$ for $48 \mathrm{hr}$ to determine herbage mass. Weekly net HA rates were calculated after using the weekly calibration equations to adjust the visual paddock scores. Herbage accumulation was calculated by the difference between the weekly scores where a paddock had not been grazed or made into silage. Monthly HA was calculated as the sum of the average weekly NHA rates.

Monthly pasture growth at Paratu Road was measured from June 1995 to May 2020, using the average from $3 \times 0.28 \mathrm{~m}^{2}$ exclusion cages within a single paddock. Two $0.01 \mathrm{~m}^{2}$ quadrats from each cage were cut to $2.5 \mathrm{~cm}$ height above ground level at the start of each month. Cages remained in place for 12 months before being shifted to a new site, which usually was a different paddock. Monthly data on HA were summed from November to April each year to estimate summerautumn pasture yield.

\section{Statistical analyses}

All long-term time series analyses were conducted using the R software (R Core Writing Team 2013).
VCN rainfall, soil moisture (stress days), and measured and modelled pasture growth (net HA) at each site were examined using linear regression, scatterplot smoothing utilizing locally weighted polynomial regression (LOWESS, Cleveland 1979), and box plots by decade. If required to achieve homogeneity of variance, data were transformed for analysis. In order to test for equal variances between decades, Bonferroni $95 \%$ confidence intervals, adjusted for multiple comparison, were used. There was no significant indication of unequal variances for the different decades (Tables 2 and 3).

Box plot graphs by decade are presented except for measured and modelled pasture growth due to Paratu Road measured data spanning only 2.6 decades. Where the slope of the linear regression was significantly different from zero, they are reported in the text and in tables. Differences were considered significant at $\mathrm{P}<0.05$ and a statistical trend declared at $\mathrm{P}<0.10$.

\section{Results}

\section{Climate trends}

Cumulative rainfall for November to April measured at Ruakura from 1954 to 2020 was highly variable (mean $516 \mathrm{~mm}$, range $265 \mathrm{~mm}$ to $792 \mathrm{~mm}$ ). There was a linear trend toward lower rainfall $(-1.3 \mathrm{~mm} / \mathrm{yr}, \mathrm{P}=0.075$, Table 1) over time. The most recent decade showed greater variability in summer-autumn rainfall with the $\mathrm{CV}$ increasing from between $19 \%$ and $22 \%$ in the preceding decades to $32 \%$ in 2010-2019 (Table 2).

There was a trend toward lower interpolated summerautumn rainfall over the past 6 decades (Table 1, -1.75 $\mathrm{mm} / \mathrm{yr}$ ) for Scott Farm and a statistically significant decline at Paratu Road (Table 1, -1.99 mm/yr).

There were no significant differences in interpolated

Table 1 Statistical significance (P-values) of linear trends in cumulative November-April rainfall, moisture stress index, and pasture growth (net herbage accumulation, HA) for two locations in Waikato. Years for which data were available are indicated in brackets.

\begin{tabular}{lll}
\hline Variable & \multicolumn{2}{c}{ Location } \\
\cline { 2 - 3 } & Scott Farm & Paratu Road \\
\hline Measured rainfall & $\begin{array}{l}0.075 \\
(1954-2020)\end{array}$ & Not measured \\
\hline Interpolated rainfall $^{1}$ & 0.06 & 0.03 \\
& $(1960-2020)$ & $(1960-2020)$ \\
\hline Moisture stress index & 0.02 & 0.015 \\
& $(1972-2020)$ & $(1972-2020)$ \\
\hline Simulated net HA & 0.03 & 0.03 \\
& $(1977-2020)$ & $(1977-2020)$ \\
\hline Measured net HA & NS & NS \\
& $(1979-2020)$ & $(1995-2020)$ \\
\hline
\end{tabular}

${ }^{1}$ Virtual Climate Network 


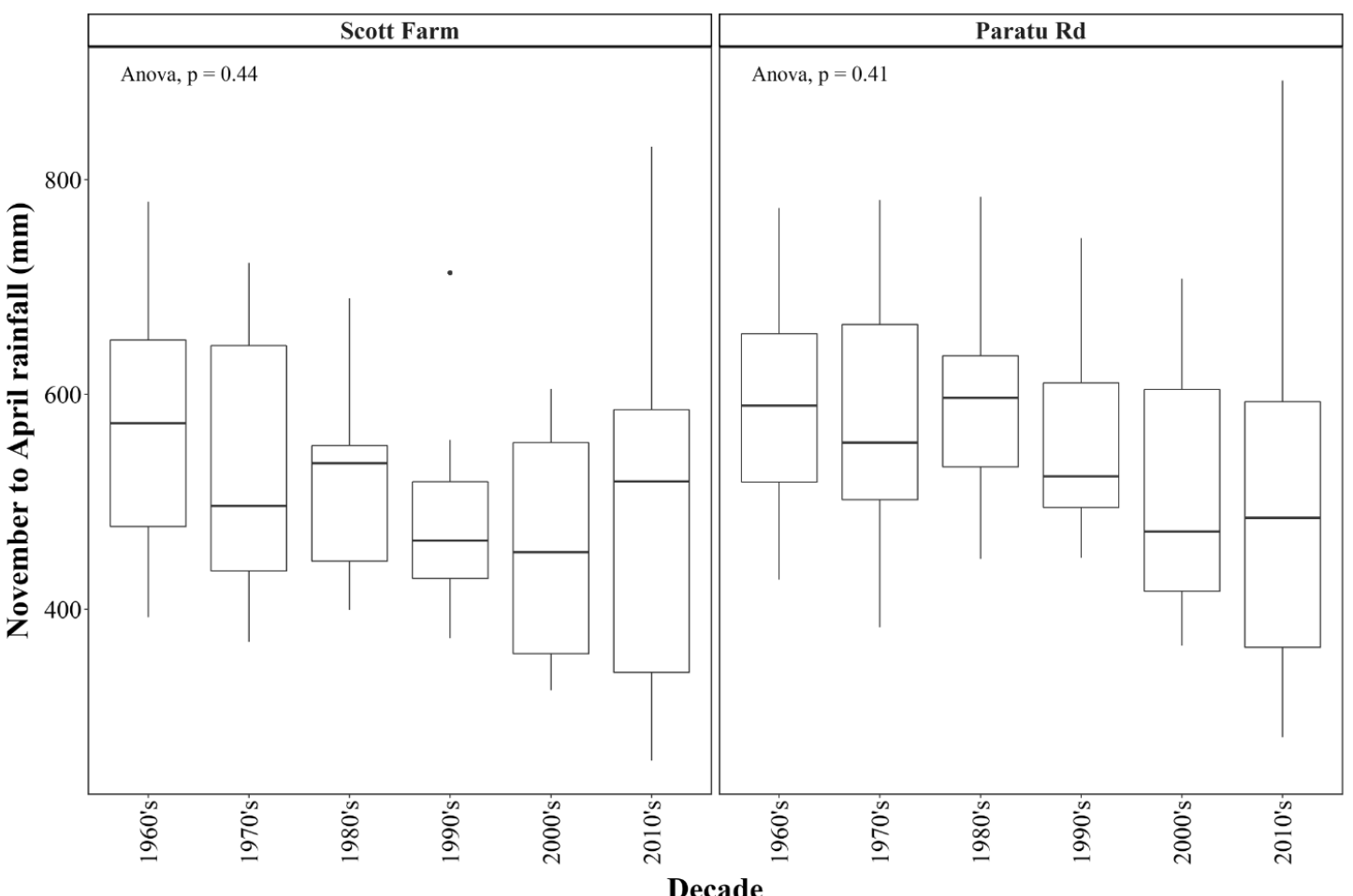

Figure 1 Cumulative summer-autumn (November-April) interpolated rainfall $(\mathrm{mm})$ by decade from VCN climate data sites representing Scott Farm and Paratu Road. Boxes encompass the middle quartiles, plus the median (solid line). Whiskers represent upper and lower quartiles.

rainfall among decades (Figure 1), although the CV increased in the most-recent decade (Table 3 ) at both sites, similar to the pattern in measured rainfall at Ruakura noted in Table 1.

When individual months (November to April) were analysed for trends in interpolated rainfall, there was a significant decline for November for both locations ( $\mathrm{P}=0.021$ for Scott Farm; $\mathrm{P}=0.005$ for Paratu Road) but no significant trends were observed for the other months at either location (data not presented).

\section{Soil moisture stress days}

There was a significant linear increase in stress days from 1972-2020 at both sites (Table 1). There were no differences among decades in calculated stress days at Scott Farm (Figure 2), but a significant increase in stress days in the most recent decade compared with earlier decades at Paratu Road.

Linear regression analysis of summer-autumn stress days by individual months showed significant increases over time for November, December and January at Scott Farm, and for November and January at Paratu Road with a statistical trend toward an increase in December at Paratu Road (Table 4).

\section{Simulated net HA}

The model predicted a significant linear decline for summer-autumn pasture growth from 1977 to 2020 for both VCN nodes representing Scott Farm and Paratu Road (Table 1). However, the linear component

Table 2 Mean summer-autumn rainfall at Ruakura (November-April, mm), 1954-2019 by decade. Includes standard deviation (SD) from mean and coefficient of variation, $\mathrm{CV} \%$.

\begin{tabular}{llrrrrrrrr}
\hline Decadal variability & \multicolumn{10}{c}{ Decade } \\
\cline { 3 - 10 } & & $\mathbf{1 9 5 0}$ & $\mathbf{1 9 6 0}$ & $\mathbf{1 9 7 0}$ & $\mathbf{1 9 8 0}$ & $\mathbf{1 9 9 0}$ & $\mathbf{2 0 0 0}$ & $\mathbf{2 0 1 0}$ & Overall mean \\
\hline Nov-Apr rainfall & Mean & 574 & 556 & 498 & 548 & 489 & 488 & 505 & 516 \\
& SD & 118 & 109 & 105 & 103 & 97 & 108 & 164 & 119 \\
& CV\% & 21 & 20 & 21 & 19 & 20 & 22 & 32 & 23 \\
\hline
\end{tabular}




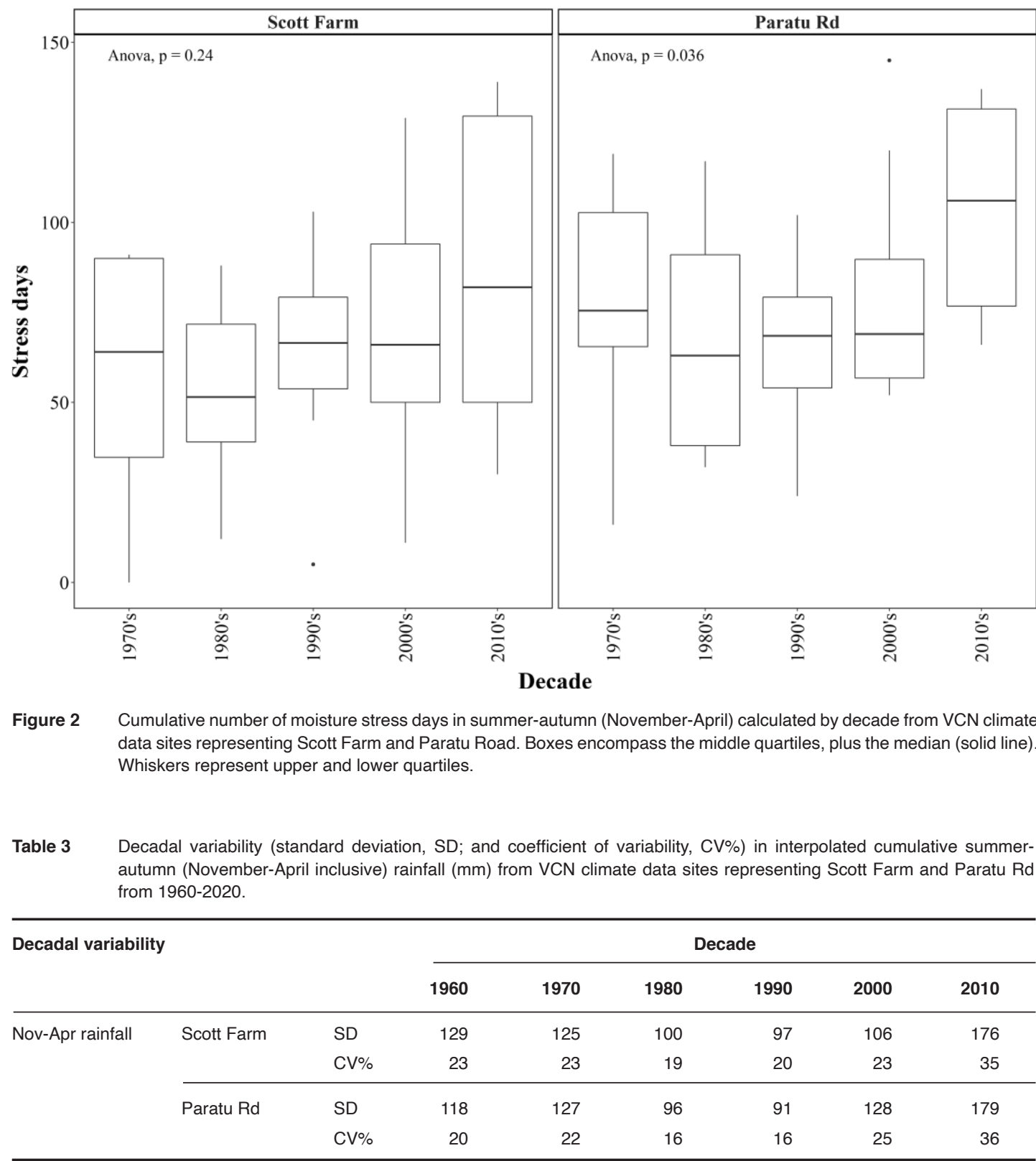

Table 4 Linear trends (slope) and statistical significance (P-value) by month for summer-autumn moisture stress days at Scott Farm and Paratu Road, 1972-2020.

\begin{tabular}{|c|c|c|c|c|c|c|c|c|}
\hline \multirow{2}{*}{\multicolumn{2}{|c|}{ Linear trend by month }} & & \multicolumn{5}{|c|}{ Month } & \multirow{3}{*}{$\begin{array}{l}\text { Apr } \\
\text { NS }\end{array}$} \\
\hline & & & \multirow{2}{*}{$\begin{array}{c}\text { Nov } \\
0.044\end{array}$} & \multirow{2}{*}{$\begin{array}{r}\text { Dec } \\
<0.001\end{array}$} & \multirow{2}{*}{$\begin{array}{c}\text { Jan } \\
0.025\end{array}$} & \multirow{2}{*}{$\frac{\text { Feb }}{\text { NS }}$} & \multirow{2}{*}{$\begin{array}{c}\text { Mar } \\
\text { NS }\end{array}$} & \\
\hline Stress days & Scott Farm & P-value & & & & & & \\
\hline & & Slope & +0.07 & +0.3 & +0.25 & +0.02 & +0.08 & +0.02 \\
\hline & Paratu Rd & P-value & 0.004 & 0.081 & 0.038 & NS & NS & NS \\
\hline & & Slope & +0.20 & +0.18 & +0.22 & +0.02 & +0.09 & +0.11 \\
\hline
\end{tabular}




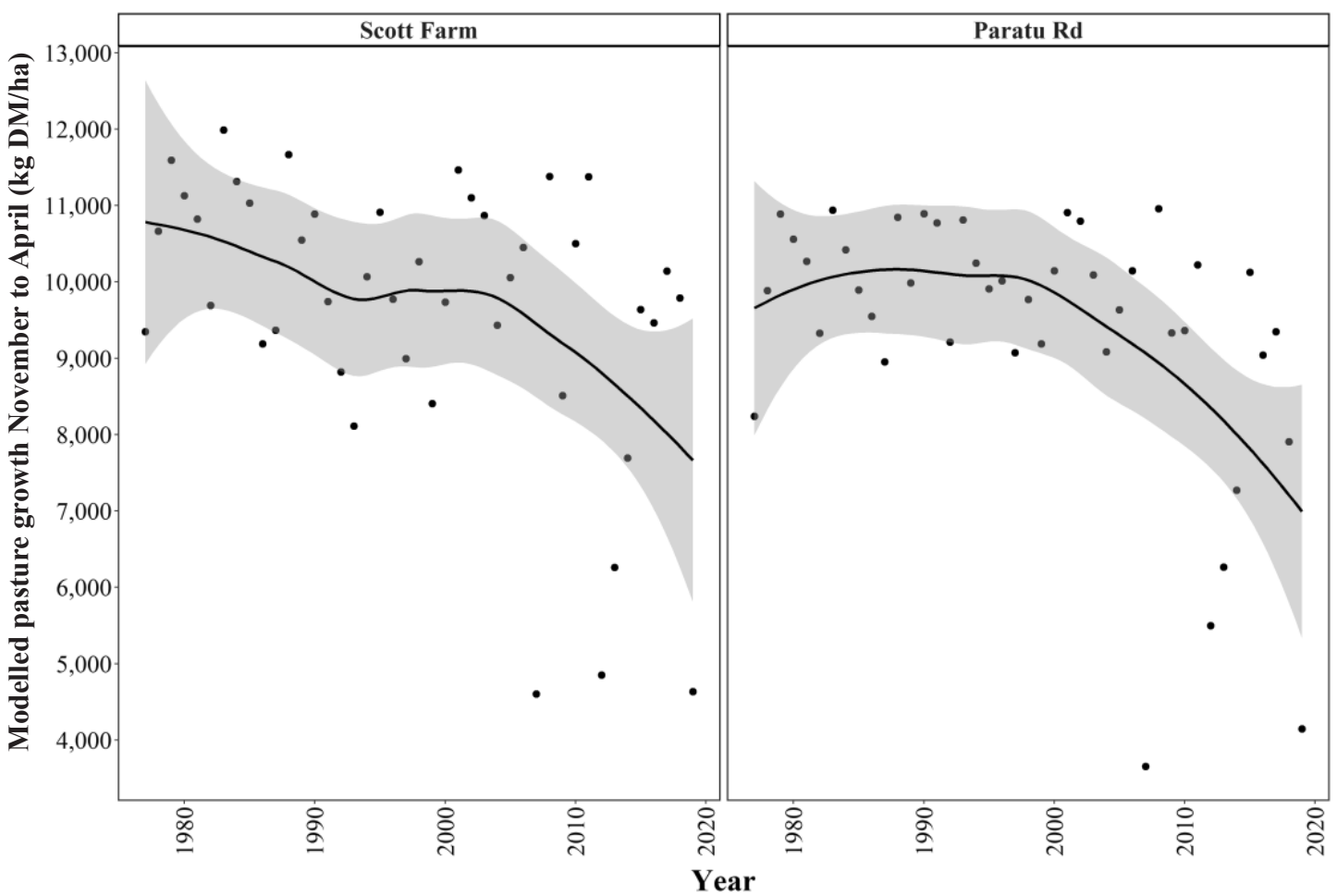

Figure 3 Predicted summer-autumn net HA (November-April) from 1977-2020 for Scott Farm and Paratu Road. Shaded areas are $95 \%$ confidence intervals.

only explained 20\% (Scott Farm) and 22\% (Paratu Road) of the overall variation in predicted cumulative summer-autumn HA. The LOWESS analysis (Figure 3) indicated that most of the decline in predicted pasture growth occurred from the mid-1990s to 2020 .

\section{Observed net HA}

Mean cumulative net HA for November to April inclusive measured during the Ruakura No. 2 Dairy and Scott Farm sequence was 9.4 t DM/ha \pm 1.4 SD over 41 years. At Paratu Road, mean cumulative net HA for November to April was $7.1 \mathrm{t} \mathrm{DM} / \mathrm{ha} \pm 1.6 \mathrm{SD}$ over 26 years. Inter-annual variation in net HA was greater at Paratu Road $(\mathrm{CV}=22 \%)$ compared with Ruakura/Scott Farm $(\mathrm{CV}=14 \%)$. There was no linear trend over time in NHA for either site (Table 1).

\section{Discussion}

The results suggest that farmers in at least two locations in central Waikato are facing a trend of increased frequency of summer-autumn soil moisture deficits while still coping with substantial (and possibly increasing) variability in rainfall between years. Salinger \& Porteous (2014) reported a distinct trend towards higher values of drought indices over a 72-year period, including the region covered in our analysis.
The variability between years dominated much of the available data making detection of trends difficult. For example, it was difficult to confirm the trend in summer-autumn rainfall at Ruakura over 70 years, as the linear trend only approached significance with a very low regression co-efficient $\left(\mathrm{P}=0.075, \mathrm{r}^{2}=0.048\right)$.

We used three independent statistical methods to explore trends within the data, each with their own respective advantages and limitations. The chosen time period for analysis, and the influence of individual year data points in relation to the time sequence of available data, can influence the sensitivity of a linear regression. Because of climatological evidence for decadal-scale oscillations in weather patterns, we grouped the data by decade. This represents a somewhat arbitrary decision of which 10 years will constitute a decadal group. We explored this despite the loss of statistical power compared with using individual years for linear or LOWESS analysis. We present box plots graphs by decade as they give a much better depiction of any change in variability than the scattered individual year patterns used in the linear regression and LOWESS graphs.

The availability of VCN data strengthened our search for evidence and allowed inclusion of the site at Paratu Road with recorded pasture production for 26 years (Figure 4). Keeping monthly rainfall records on Paratu 


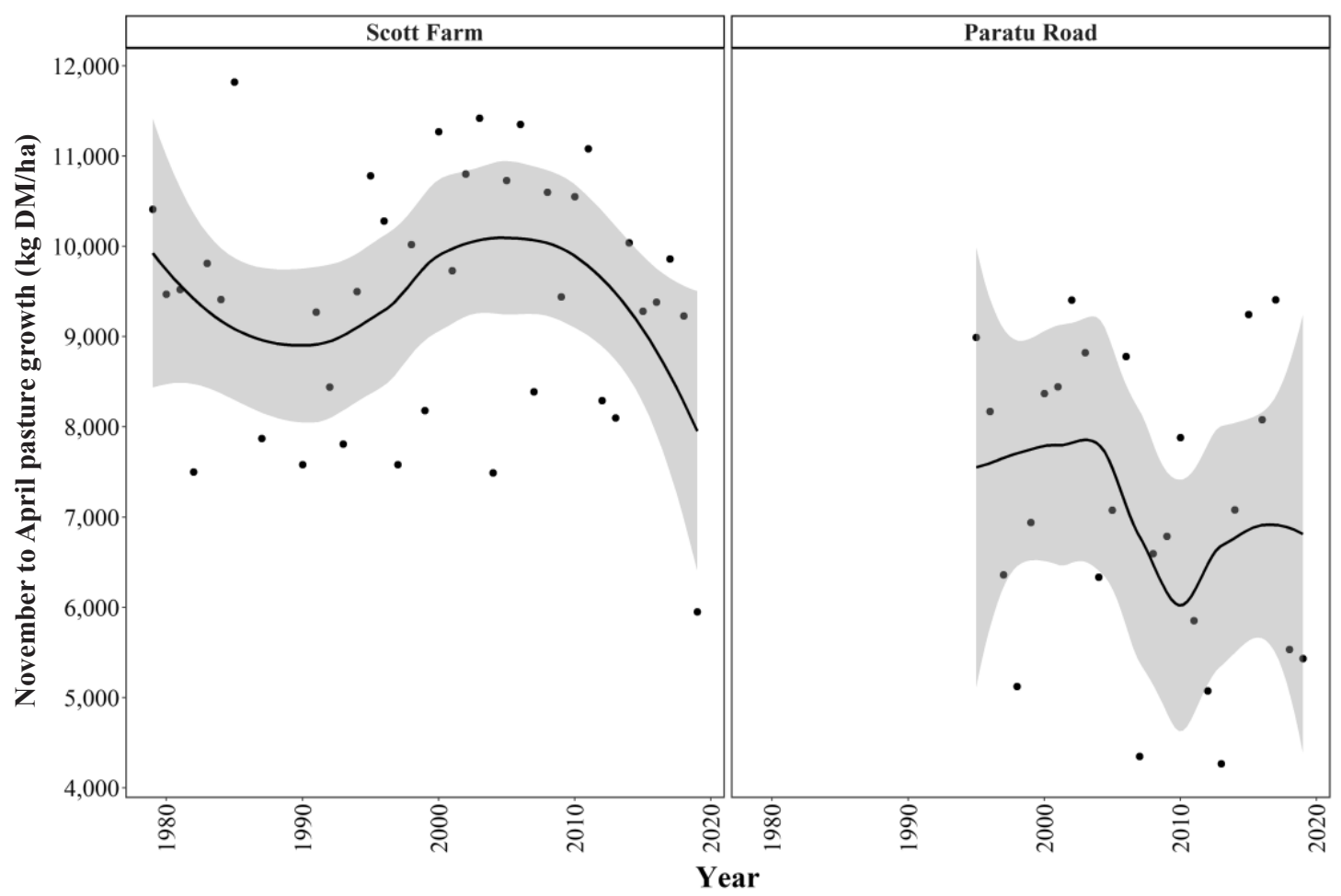

Figure 4 Measured summer-autumn net HA (November-April, kg DM/ha) for Ruakura/Scott Farm (1979-2020) and Paratu Road (1995-2020). Shaded areas are 95\% confidence intervals.

Road was abandoned many years ago after recognition of the large effects that the timing of individual rainfall events can have on soil moisture levels and, therefore, pasture growth. The VCN data allowed the calculation of daily soil moisture balances and provided information on the frequency of "stress days", where soil moisture was limiting pasture growth.

The analyses of VCN data supported farmer concerns of increasingly drier and more variable summers. While the VCN data box plot for rainfall by decade for both sites showed no significant trend at Scott farm there was a linear trend $(\mathrm{P}=0.06)$ towards reduced summerautumn rainfall, and for Paratu Road there was a significant $(\mathrm{P}=0.03)$ linear decline in summer-autumn rainfall over the past 6 decades. For Paratu Road the boxplot by decade also showed a significant increase in soil moisture deficit days for the most recent decade (Figure 2).

Additional analysis of VCN data for each location by month showed November to be the only month with a consistent and significant decline in rainfall over time and this resulted in significant increases in soil moisture stress days from November to January (Table 3 ).

Linking trends in climate data to measured pasture production is difficult because of the lack of actual long-term pasture growth measurements from any one location. Long-term sequential records for annual pasture growth from research sites in Waikato before 1980 were difficult to find although some publications presented data for shorter periods (e.g., Mcaneney et al. (1982) covered 1953-1966 and Baars (1976) covered 1954-1970).

For measured pasture growth we were unable to detect any significant trends over time at both locations (Figure 4). This contrasts with the simulated summer-autumn pasture growth (Figure 3). Simulated cumulative NHA for November-April fell broadly within the range measured at Scott Farm (5000-12000 $\mathrm{kg} \mathrm{DM} / \mathrm{ha})$. For Paratu Road the model predicted higher pasture growth (by $\sim 2000 \mathrm{~kg} \mathrm{DM} / \mathrm{ha}$ on average) than the measured data. A possible explanation for the dissimilarity in the long-term trend between measured and simulated data sets is that the pasture growth model uses only local environmental conditions (weather and soil) in its predictions, whereas on-farm measurements of pasture growth will also be influenced up or down by other factors, such as reducing feed demand by culling, $\mathrm{N}$ applications, supplement use, rotation length and managing grazing intensity (Reynolds 2013).

The significant decline in summer-autumn pasture growth predicted by the model perhaps confirms that the trends found for declining summer-autumn rainfall, 
including November, at both farms are creating challenges for managing feed supply and feed demand for Waikato dairy farmers, especially on soil types with lower PAW e.g., Paratu Road.

It is evident that the magnitude of variation appears to have increased for both sites in the most recent decade (Tables 1 and 2; Figures 1 and 2). This is consistent with climate projections for increases in the frequency of extreme conditions (precipitation, temperature and wind, Mullan et al. 2018). Increased variability is a likely contributor to reduced resilience of ryegrass pastures (Lee et al. 2017). It also impacts on the choice of farm system through a reduction in opportunity to carry forward surplus feed from one season to the next and increases other risk factors such as soil physical damage associated with increased crop/ pasture establishment method and management.

The increased frequency of drier summers in the past decade (Figures 2 and 3) will also be influencing farm management changes over time due to the reduced amount of pasture available in drier summers. For example, Glassey (2011) reported that $100 \mathrm{~mm}$ less rainfall between December and April was associated with $850 \mathrm{~kg} \mathrm{DM} / \mathrm{ha}$ less pasture grown.

Farm management practices have been adapted over time at the Paratu Road farm in response to the variability in farm-specific summer-autumn pasture growth measurements. These include:

- An increase in weed spraying because of more Setaria pumilia (Poir.) (yellow bristle grass) and other $\mathrm{C}_{4}$ grasses.

- Increased use of winter-active ryegrass cultivars such as 'Shogun' integrated with a summer cropping programme.

- Use of three Herd Homes ${ }^{\mathrm{TM}}$ in summer to help control post-grazing residuals and mitigate heat stress for cows.

- Increased imported feed in the last 12 years to mitigate the variability of pasture production.

- A change (4 years ago) to $25 \%$ of the herd starting calving in March, with a winter milk contract. This matches the measurements of winter pasture growth being much more reliable than in summer.

- Nitrogen fertiliser use has reduced to about $120 \mathrm{~kg}$ $\mathrm{N} / \mathrm{ha} / \mathrm{yr}$ and is largely confined to spring (or autumn), when soil moisture is most reliable.

Some of these changes, such as use of the Herd Homes and more imported feed, provide options for tactical management of pastures over late springsummer-autumn to, for example, prevent over-grazing and support pasture persistence. However, farm system adaptations such as those mentioned above bring additional costs into the farm system. In situations where variability in summer-autumn growing conditions is placing perennial ryegrass pastures under significant stress and threatening their persistence, there is also a cost of 'doing nothing' as farmers become trapped in a cycle of re-grassing and re-cropping (Dodd et al. 2018).

\section{Conclusions/Practical implications/Relevance}

This study suggests that farmers near the locations examined are likely to have experienced increased variability and frequency of summer moisture deficits, which our pasture growth modelling shows is likely to have been accompanied by a declining trend over time in pasture accumulation rates.

Depending on their farm's risk profile for ryegrass/ clover pasture resilience, farmers in the upper North Island will need to explore alternatives to perennial ryegrass to maintain their future home-grown feedbase, or adapt their pasture management to cope with the increasing risk of summer moisture deficit.

The integration of VCN data with pasture growth models appears to be an opportunity to help farmers understand how their local climate is behaving and should inform farm management decisions that help them cope with the increasing risk of summer soil moisture deficits.

Adding more sophisticated analysis such as thermal time accumulation, and other statistical methods, could add increased certainty to these messages.

\section{ACKNOWLEDGEMENTS}

Grant Wills provided 26 years of monthly pasture growth data for his dairy farm at Paratu Road, Walton. Barbara Kuhn-Sherlock (DairyNZ) provided valuable statistical advice. We are also grateful to the many technicians who have contributed to the collection and storage of monthly pasture growth data over the years at Ruakura No. 2 dairy and Scott Farm.

\section{REFERENCES}

Baars JA. 1976. Seasonal distribution of pasture production in New Zealand. IX Hamilton. New Zealand Journal of Experimental Agriculture 4: 157161. https://doi.org/10.1080/03015521.1976.10425 862

Cleveland WS. 1979. Robust locally weighted regression and smoothing scatterplots. Journal of American Statistical Association 74: 829-836. https://doi.org/10.1080/01621459.1979.10481038

DairyNZ. 2021. Forage Value Index. The DairyNZ FVI Handbook 2021 Edition. 47p. Retrieved 19 February 2021 from: https://www.dairynz.co.nz/ media/5794012/forage-value-index-handbook-2021final.pdf.

Dodd MB, Chapman DF, Ogle G. 2018. Re-grassing trends and drivers in the New Zealand dairy industry. Journal of New Zealand Grasslands 80: 177-183. https://doi.org/10.33584/jnzg.2018.80.342 
Ferguson CM, Barratt BIP, Bell N, Goldson SL, Hardwick S, Jackson M, Jackson TA, Phillips CB, Popay AJ, Rennie G, Sinclair S, Townsend R, Wilson M. 2019. Quantifying the economic cost of invertebrate pests to New Zealand's pastoral industry. New Zealand Journal of Agricultural Research 62: 255-315. https://doi.org/10.1080/00288233.2018.14 78860

Folland CK, Renwick JA, Salinger MJ, Mullan AB. 2002. Relative influences of the Interdecadal Pacific Oscillation and ENSO on the South Pacific Convergence Zone. Geophysical Research Letters 29: 21-1 to 21-4. https://doi.org/10.1029/2001GL014201

Glassey CB. 2011. Summer pasture yield variation in a central Waikato location from 1979 to 2010: implications for pasture persistence. In: Mercer CF. Ed. Pasture Persistence Symposium. Grassland Research and Practice Series 15. Dunedin, New Zealand: New Zealand Grassland Association, pp. 15-20. https://doi.org/10.33584/rps.15.2011.3214

Hodgson J. 1979. Nomenclature and definitions in grazing studies. Grass and Forage Science 34: 11-18. https://doi.org/10.1111/j.1365-2494.1979.tb01442.x

Lee JM, Thom ER, Waugh CD, Bell NL, McNeill M.R, Wilson DJ, Chapman DF. 2017. Trajectory and causes of decline in the botanical composition of dairy-grazed pasture in the Waikato. Journal of New Zealand Grasslands 79: 89-96. https://doi. org/10.33584/jnzg.2017.79.546

Macdonald KA, Penno JW. 1998. Management decision rules to optimise milksolids production on dairy farms. Proceedings of the New Zealand Society of Animal Production 58: 132-135.

Mcaneney KJ, Judd MJ, Weeda WC. 1982. Loss in monthly pasture production resulting from dryland conditions in the Waikato. New Zealand Journal of Agricultural Research 25: 151-156. https://doi.org/1 0.1080/00288233.1982.10420904

Mullan B, Sood A, Stuart S, Carey-Smith T. 2018. Climate Change Projections for New Zealand: Atmosphere Projections Based on Simulations from the IPCC Fifth Assessment, 2nd Edition. Ministry for the Environment, Wellington, New Zealand. 131 p.

NIWA. 2020. Virtual Climate Station data and products. Retrieved 16 November 2020 from: https://niwa. co.nz/climate/our-services/virtual-climate-stations

Ogle G. 2015. Forecasting pasture growth rates across New Zealand. Retrieved 16 November 2020 from: https://www.rezare.co.nz/forecasting-pasturegrowth-rates-across-new-zealand/

$\mathrm{R}$ Core Writing Team. 2013. R: a language and environment for statistical computing. R Core Team, $\mathrm{R}$ Foundation for Statistical Computing, Vienna, Austria. Available at: www.R-project.org

Reynolds WN. 2013. Addressing on-farm management to enhance pasture productivity and persistence. Proceedings of the New Zealand Grassland Association 75: 241-244. https://doi.org/10.33584/ jnzg.2013.75.2914

Romera AJ, McCall DG, Lee JM, Agnusdei MG. 2009. Improving the McCall herbage growth model. New Zealand Journal of Agricultural Research 52: 477494. https://doi.org/10.1080/00288230909510529

Romera A, Beukes P, Clark D, Clark C, Tait A. 2013. Pasture growth model to assist management on dairy farms: Testing the concept with farmers. Grassland Science 59: 20-29. https://doi.org/10.1111/grs.12009

Salinger MJ, Porteous AS. 2014. New Zealand climate: patterns of drought 1941/42-2012/13. Weather and Climate 34: 2-19. https://doi.org/10.2307/26169741

Tait A, Henderson R, Turner R, Zheng X. 2006. Thin plate smoothing spline interpolation of daily rainfall for New Zealand using a climatological rainfall surface. International Journal of Climatology 26: 2097-2115. http://dx.doi.org/10.1002/joc. 1350

Tozer KN, Cameron CA, Thom ER. 2011. Pasture persistence: farmer observations and field measurements. In: Mercer CF. Ed. Pasture Persistence Symposium. Grassland Research and Practice Series 15. Dunedin, New Zealand: New Zealand Grassland Association, pp. 25-30. https:// doi.org/10.33584/rps.15.2011.3216 
